\title{
Budownictwo i architektura od powstania Zakopanego do odzyskania przez Polskę niepodległości
}

\section{Construction and architecture from the creation of Zakopane to Polish independence}

\section{Streszczenie}

Pierwsze wzmianki o Zakopanem pochodzą z początku XVII w. Od końca lat 30. XIX w. lecznictwo klimatyczne przyczyniło się do rozwoju Zakopanego jako miejscowości letniskowej i uzdrowiskowej. Przyspieszenie rozwoju nastąpiło w końcu XIX w. dzięki popularyzacji walorów klimatycznych miejscowości. W 1886 r. miejscowość uzyskała status stacji klimatycznej. W tym czasie w Zakopanem rozpowszechniała się architektura w tzw. stylu szwajcarskim, a Stanisław Witkiewicz zapoczątkowł batalię o „styl góralski” w miejscowej architekturze. Kolejny „skok cywilizacyjny” nastąpił na początku XX w., po doprowadzeniu kolei do samego Zakopanego. W centrum wsi zaczęły pojawiać się budynki murowane.

Słowa kluczowe: Zakopane, Tatry, szałasy pasterskie, podhalańskie budownictwo ludowe, styl szwajcarski, styl zakopiański, architektura eklektyczna

\begin{abstract}
The first documented mentions of Zakopane come from the early $17^{\text {th }}$ century. From the late 1830 s, climatic medicine contributed to the development of Zakopane as a summer and spa town. Acceleration of development occurred at the end of the $19^{\text {th }}$ century as a result of the popularisation of the town's climatic values. In 1886, the town obtained the status of climate station. At that time, the Swiss style of architecture was becoming widespread for summer buildings and Stanisław Witkiewicz back to the beginning of the battle for the 'highlander style' in local architecture. Another 'civilisational leap' occurred at the beginning of the $20^{\text {th }}$ century, after the railway was brought to Zakopane itself. In the centre of the village, brick buildings began to appear.
\end{abstract}

Keywords: Zakopane, Tatra Mountains, shepherds' huts, Podhale folk architecture, Swiss style, Zakopane style, eclectic architecture 


\section{ROZWÓJ ARCHITEKTURY W TATRACH I ZAKOPANEM}

Dzisiejsze Zakopane powstało dzięki powiązaniu dwóch odrębnych czynników gospodarczych złączonych ze sobą ekonomicznie - rolniczo-pasterskiego osadnictwa u podnóża Gubałówki (koniec XV w.) z centrum w obrębie tzw. nawsia (usytuowanego we wschodniej części ulicy Kościeliskiej i stanowiącego najstarszą część wsi Zakopane) oraz osadnictwa przemysłowego skupionego w obrębie górniczo-hutniczej osady w dzisiejszych Kuźnicach (ok. poł. XVIII w.). Komunikację między tymi ośrodkami stanowiły Krupówki, ciągnące się pierwotnie od zbiegu ul. Kościeliskiej i Nowotarskiej aż do Hut Hamerskich „Zakopane”. Tak więc krzyżowanie różnych interesów gospodarczych w Tatrach leżało od zarania dziejów u podstaw rozwoju Zakopanego.

Wypasający owce na halach tatrzańskich pasterze ze wsi Niżnego Podhala wznosili na polanach szałasy i koliby pasterskie. Był to początek podhalańskiego budownictwa ludowego w tym rejonie. Pierwsze formy architektoniczne obce ludowej tradycji przyniesione zostały przez hawiarzy i hamerników prawdopodobnie jeszcze w XVII w. Budownictwo ludowe przybrało zdecydowane formy stylistyczne na przełomie XVIII i XIX w., a dworsko-przemysłowe na początku XIX w.

W pierwszych latach XIX w. Tatry stały się też magnesem przyciągającym turystów, a w tatrzańskim klimacie zaczęto upatrywać właściwości leczniczych. Tak więc Zakopane stało się ośrodkiem turystyczno-uzdrowiskowym ściągającym coraz większe rzesze turystów, letników i kuracjuszy. Sprzyjało to nadal rozwojowi w Zakopanem obu tendencji - obok budownictwa ludowego, a potem architektury regionalnej (podhalańskie budownictwo ludowe, styl zakopiański, styl zakopiański drugi, nowy regionalizm - wolny funkcjonalizm, styl nowozakopiański po współczesny regionalizm), rozwijał się nurt kosmopolityczny (klasycyzm, styl szwajcarski, historyzm i eklektyzm, modernizm i funkcjonalizm, socmodernizm po późny modernizm).

To wczesne zróżnicowanie form architektonicznych pod Giewontem wpłynęło na dzisiejszy wygląd Zakopanego i stanowi wiecznie powracający dylemat zarówno dla planistów formułujących wytyczne architektoniczne do projektowania, jak i dla architektów będących autorami dokumentacji wznoszonych w mieście budynków - architektura regionalna czy uniwersalna? Dotyczy to także problematyki ochrony zabytków w mieście. Bez odpowiedzi pozostawię pytanie: „Czy pod Giewontem jest miejsce dla nowoczesnej architektury performatywnej, bezkształtnie rozpełzającej się po terenie i pomiędzy zabudową historyczną?". 


\section{OKRES PRZEMYSŁOWEGO WYKORZYSTANIA TATR}

\subsection{CZYNNIKI ROZWOJU ZAKOPANEGO ${ }^{1}$}

Zakopane powstało na przełomie XVI i XVII wieku za panowania króla Stefana Batorego jako osada pasterska na fali wygasających już wędrówek wołoskich. Jeszcze w połowie XVIII stulecia, za czasów panowania Stanisława Augusta Poniatowskiego, składało się ono z szeregu śródleśnych osad pastersko-rolniczych, rozrzuconych po lasach pańskich. Poszczególne osady łączyła sieć dróg i ścieżek, których zaczątkiem były zapewne szlaki pasterskie. W tym czasie po północnej stronie Tatr nabierać zaczęły znaczenia górnictwo i hutnictwo - początkowo kruszcowe, a później żelaza - ale ich rozkwit i wpływ na rozwój Zakopanego, decydujący o jego późniejszej roli, nastąpiły już w Polsce porozbiorowej, w zaborze austriackim².

Od końca lat 30. XIX w. większą rolę zaczęło odgrywać lecznictwo klimatyczne, które początkowo polegało na wykorzystaniu zarówno walorów naturalnych górskiego klimatu, jak i tradycyjnego zdrowego pożywienia pasterskiego („kuracje żentycowe”) oraz odpadów produkcji hutniczej („kąpiele żużlowe”). Wraz z napływem kuracjuszy i letników stopniowo rozwijała się też turystyka letnia.

Zmiany te przyczyniły się do rozwoju Zakopanego jako miejscowości letniskowej i uzdrowiskowej. Sprzyjało temu powstanie w 1847 r. parafii, którą ufundowali Klementyna i Edward Homolacsowie, czym rozpoczęli stopniowy proces cywilizacji tej dzikiej dotąd okolicy ${ }^{3}$. Znaczne przyspieszenie tego rozwoju nastąpiło w pod koniec XIX w. dzięki działalności Towarzystwa Tatrzańskiego (1873 r.) oraz popularyzacji walorów klimatycznych miejscowości przez dra Tytusa Chałubińskiego (od 1873 r.) $)^{4}$.

Postęp turystyki zimowej i narciarstwa w pierwszych latach XX w. stał się kolejnym bodźcem do rozwoju miejscowości. I tak Zakopane, uważane pod koniec XIX w. za „Ietnią stolicę Polski”, od połowy lat 20. XX w. okrzyknięte zostało „zimową stolicą Polski”. Przyznanie Zakopanemu organizacji Mistrzostw Świata FIS w 1929 i 1939 r. ugruntowało jego renomę.

Turystyka letnia i zimowa oraz narciarstwo stanowiły także podstawy rozwoju Zakopanego w początkach Polski powojennej, a kolejne Mistrzostwa Świata FIS w 1962 r. podtrzymały jego rangę także w nowej rzeczywistości polityczno-gospodarczej ${ }^{5}$.

\subsection{PODHALAŃSKIE BUDOWNICTWO LUDOWE}

Zaczątkiem budownictwa ludowego w Tatrach i u ich podnóża były szałasy i koliby pasterskie, z których zapewne korzystali także hawiarze i poszukiwacze skarbów. Były to obiekty tymczasowe, wznoszone naprędce, przeważnie bez udziału wykwalifikowanych cieśli. Do najbardziej charakterystycznych należały koliby kamienne, szałasy niskozrębowe (il. 1) oraz wysokozrębowe wąskofrontowe i szerokofrontowe ${ }^{7}$. 
Gdy osadnictwo stałe dotarło pod Giewont, podstawowym typem zabudowy były zagrody jednobudynkowe (chałupa jednoizbowa z sienią oraz stajnia), które pod koniec XVIII w., a powszechniej w 1 poł. XIX w., zastępowały zagrody dwubudynkowe - chałupa dwuizbowa z sienią oraz osłaniający ją od strony zachodniej budynek gospodarczy (tzw. L-ka). W Zakopanem rozpowszechniły się dwa zasadnicze typy budynków mieszkalnych - chałupa śląsko-spiska oraz klasyczna chałupa podhalańska.

Główne różnice w architekturze tych obiektów wynikały z rzutu poziomego i rozkładu pomieszczeń. Najstarsze rozplanowanie wiąże się z rzutem wydłużonego prostokąta, na którym sień, „izba czarna” oraz „biała” (ewentualnie z komorą) rozmieszczone były w układzie jednotraktowym, w amfiladzie. Układ ten, wywodzący się z jednoizbowego domu śląsko-spiskiego, rozpowszechnił się na terenie całego północnego Podtatrza. Na Skalnym Podhalu, zastąpił go bardziej symetryczny, również o rzucie wydłużonego prostokąta, z „izbą czarną" i „białą” rozlokowanymi po obu stronach sieni (przy „izbie białej” często występowała komora), charakterystyczny dla klasycznej chałupy podhalańskiej ${ }^{8}$ (il. 2).

\subsection{ARCHITEKTURA DWORSKA I PRZEMYSŁOWA ${ }^{9}$}

Stosunkowo wcześnie pojawiło się w Zakopanem budownictwo i architektura kosmopolityczna, a mianowicie budownictwo przemysłowe i dworskie. Reprezentowały one znaną z innych terenów Galicji formę prowincjonalnego późnego baroku i klasycyzmu. Na przełomie XVIII i XIX w. dwór barokowy uległ przekształceniu w skromny dworek klasycystyczny, o tynkowanych i bielonych ścianach z gankiem od frontu zwieńczonym daszkiem o trójkątnym szczycie, wspartym na okrągłych kolumnach. Budynki reprezentujące taką architekturę powstały w Kuźnicach na początku lat 30. XIX w. - m.in. dwór Homolacsów (il. 3), dworki urzędników Zakładu (tzw. oficjalistów), karczma, wozownia, a także obiekty typowo przemysłowe, jak np. zakład wielkopiecowy i fryszerski.

Nurt późnobarokowy w ludowym wydaniu reprezentował pierwszy zakopiański kościół pw. św. Klemensa (1847-1851) wybudowana z inspiracji Klementyny i Edwarda Homolacsów, a elementy późnoklasycystyczne (czterospadowy stromy dach gontowy i symetryczny podział elewacji frontowej) pojawiły się w budynku plebani (1851) (il. 4).

\section{STACJA KLIMATYCZNA (1886-1918)}

\subsection{CHAtUPY LETNISKOWE ${ }^{10}$}

Rozwojowi Zakopanego sprzyjało doprowadzenie w 1884 r. kolei z Krakowa do Chabówki. Lansowanie miejscowości jako uzdrowiska, wspierane działalnością Towarzystwa Tatrzańskiego oraz propagowanie jego walorów klimatycznych, m.in. przez dra Tytusa 
Chałubińskiego i Ignacego Baranowskiego, doprowadziło w efekcie, w 1886 r., do uznania miejscowości jako Stacji Klimatycznej. Od lat 90. XIX w. rozwój uzdrowiska wspierany był przez nowego właściciela dóbr zakopiańskich, Władysława hr. Zamoyskiego, który nabył je w 1889 r. na licytacji w Nowym Sączu.

W tym czasie następował stopniowy rozwój budownictwa podhalańskiego, m.in. zaczęto adaptować poddasza na cele mieszkalne, jak np. w chałupie Macieja Sieczki Przewodnika na Sobczakówce (ok. 1860) (il. 5), a także budowano dwutraktowe chałupy letniskowe, jak np. chałupa Macieja Sieczki Kulawego przy ul. Kościeliskiej (1865, obecnie nr 52) czy chałupa Gąsieniców Sobczaków przy Drodze do Rojów (ok. 1830, rozbudowana ok. 1870; obecnie $\mathrm{nr}$ 6). Był to jednak przede wszystkim okres rozwoju w Zakopanem architektury letniskowejpoczątkowo w stylu szwajcarskim, a w ostatniej dekadzie XIX w. także w stylu zakopiańskim.

\subsection{STYL SZWAJCARSKI - EKLEKTYZM W WILLOWEJ ARCHITEKTURZE DREWNIANEJ11}

W 4. ćw. XIX w. w Zakopanem, podobnie jak w innych uzdrowiskach karpackich, rozpowszechniała się architektura w tzw. stylu szwajcarskim, charakterystyczna dla budynków letniskowych - willi, pensjonatów, hoteli, zakładów wodoleczniczych itp. Pierwsze wille wybudowali pod Giewontem Walery Eljasz przy ul. Krupówki (1876-1877), dr Ignacy Baranowski w lesie przy ob. ul. Kościuszki (1878), Róża hr. Krasińska okazałą „Adasiówkę" przy drodze do Kuźnic (1880-1881), a dr Tytus Chałubiński w okolicach obecnej ulicy Zamoyskiego (1881-1882). W stylu szwajcarskim wznoszono również budynki użyteczności publicznej: Zakład Wodoleczniczy dra Wenantego Piaseckiego (1880-1881), Dworzec Tatrzański (1881-1882, proj. Karol Zaremba) (il. 6), Szkołę Snycerską (1883, proj. Antoni Łuszczkiewicz), Zakład Wodoleczniczy dra Andrzeja Chramca (1887).

Budynki te prezentowały szczególny rodzaj eklektyzmu w architekturze drewnianej, charakterystyczny dla architektury uzdrowiskowej. Cechowało go przemieszanie konstrukcji zrębowej ze szkieletową, rozłożyste dachy kryte gontem, a przede wszystkim liczne ganki, wykusze, werandy i balkony, a więc elementy z architektury historycznej i budownictwa ludowego różnych regionów. Całość zdobiła bogata dekoracja z wyrzynanych desek. Pod wpływem tej architektury w chałupach góralskich pojawiły się ganki, werandy i balustrady z ażurowo wycinanych desek, ale jej zasadniczy kształt i konstrukcja nie uległy zmianie.

\subsection{STYL ZAKOPIAŃSKI ${ }^{12}$}

Na 1886 r. datuje się pierwszy pobyt pod Tatrami Stanisława Witkiewicza i zapoczątkowanie batalii o „styl góralski” w miejscowej architekturze, czyli styl zakopiański - pierwszy na szerszą skalę rozpowszechniony. Pierwszą nieudaną próbą wykorzystania motywów budownictwa podhalańskiego był drewniany budynek Muzeum Tatrzańskiego wzniesiony przy ul. Chałubińskiego (1892, proj. J. P. Dziekoński) (il. 7). Na przełomie lat 1891 i 1892 Witkiewicz, 
wykorzystując formy budownictwa i zdobnictwa podhalańskiego, zaprojektował pierwszy dom w stylu zakopiańskim, którym była willa „Koliba” Zygmunta Gnatowskiego (1892-1893) przy ul. Kościeliskiej (il. 8). Według projektów Witkiewicza wzniesiono w następnych latach kolejne wille, takie jak: „Pepita” przy ul. Chałubińskiego (1893), „Korwinówka” przy ul. Zamoyskiego (późniejsza „Oksza”; 1895-1896), „Zofiówka” przy ul. Chałubińskiego (1895-1896), „Pod Jedlami” na Kozińcu (1896-1897) - uznawana za szczytowe osiągnięcie stylu, Dom Zdrowia dra Hawranka (1897-1898) przy ul. Chałubińskiego.

Nowym stylem zainteresowali się też architekci profesjonalni. W latach 1893-1894 wzniesiono wg proj. Zygmunta Dobrowolskiego i Tadeusza Stryjeńskiego Hotel-Pensjon „Skoczyska” przy ul. Kościeliskiej. Wkrótce potem wg projektów Dobrowolskiego powstało kilka willi przy ul. Jagiellońskiej, Chałubińskiego i Chramcówki. Tadeusz Stryjeński wybudował natomiast własną willę „Schodnica” na Uboczy (1894-1897), a Jan Witkiewicz-Koszczyc zaprojektował willę dla swego ojca wybudowaną na Antałówce (dzisiejsza „Witkiewiczówka", 1903-1904).

W latach 1877-1899 wzniesiony został kościół pw. św. Rodziny przy ul. Krupówki (proj. J.P. Dziekoński) (il. 9). Zanim kościół ukończono, Stanisław Witkiewicz podjął batalię o urządzenie jego wnętrza w stylu zakopiańskim. W latach 1895-1900 powstało wyposażenie kościoła (ławki, konfesjonały, witraże), urządzono kaplicę Matki Boskiej Różańcowej i św. Jana Chrzciciela. W latach późniejszych wybudowano kościół i klasztor Braci Albertynów na Kalatówkach (1898) oraz kaplicę Najświętszego Serca Pana Jezusa w Jaszczurówce (1904-1907).

Budowie coraz to nowych willi towarzyszyło lansowanie stylu zakopiańskiego na styl polski, w czym pomagała utopijna teoria głosząca, że styl zakopiański był niegdyś w Polsce powszechny. Styl zakopiański - pierwsza na ziemiach polskich szerzej rozpowszechniona koncepcja stylu narodowego - zahamował falę architektury „szwajcarskiej” w Zakopanem i zyskał też pewną popularność na dawnych ziemiach polskich (m.in.: w Wiśle, Łańcuchowie, Nałęczowie, Konstancinie, Krakowie, Lwowie, Warszawie, a nawet na Litwie - Syłgudyszki, Połąga).

\subsection{ROZWÓJ ARCHITEKTURY MUROWANEJ - EKLEKTYZM I POCZĄTKI MODERNIZMU ${ }^{13}$}

Kolejny „skok cywilizacyjny” nastąpił w pierwszych latach XX w., po doprowadzeniu kolei do samego Zakopanego (jesień 1899). Dzięki transportowi kolejowemu umożliwiającemu sprowadzanie materiałów ogniotrwałych zaistniały wówczas warunki do ograniczenia plagi pożarów, z których dwa ostatnie (w latach 1899 i 1900) przyniosły szczególnie dotkliwe zniszczenia w centrum uzdrowiska. W 1900 r. wybudowano pierwsze kamienice eklektyczne przy ul. Krupówki - hotel „Morskie Oko” (ob. nr 30), kamienicę Zwolińskich (ob. nr 37, proj. br. S. Dydko TJ) (il. 10), secesyjną kamienicę Mangla (potem Leistena, ob. nr 28), oraz typowy dla tego czasu dworzec kolejowy (proj. H. Starck). Niedługo potem powstało jeszcze kilka takich obiektów. Żywiołową, bezplanową urbanizację Zakopanego, 
która miała miejsce w latach 90. XIX w., próbowano opanować poprzez opracowanie w latach 1899-1901 pierwszego projektu regulacji. Autorem był inż. Kazimierz Engel. Realizację planu zaczęto od uregulowania potoku Bystra (1899-1901, proj. inż. K. Kostański) oraz wytyczenia wzdłuż jego biegu ul. Nad Wodą (dziś ul. Sienkiewicza).

W 1904 r. wytyczono ul. Marszałkowską (ob. ul. T. Kościuszki), która stanowiła połączenie dworca kolejowego z centrum. W kwietniu 1905 r. ruszyła jedna z najważniejszych inwestycji ówczesnego Zakopanego, a mianowicie budowa wodociągu. Projekt wykonał rok wcześniej inż. Ignacy Radziszewski, reprezentujący warszawską firmę Drzewiecki i Jeziorański. Oficjalne oddanie wodociągu nastąpiło $w$ dniach 21-22 października 1908 r. $^{14}$

Wraz z rozwojem cywilizacyjnym w centrum wsi zaczęły pojawiać się budynki murowane, które stały się zaczątkiem miejskiej tkanki Zakopanego (ul. Krupówki), rozrastającej się z biegiem lat (ul. Marszałkowska). Początkowo była to architektura w stylu zakopiańskim lub eklektyczna. Jeszcze z końcem XIX w. wzniesiono pierwsze „murowanice” w stylu zakopiańskim - murowany budynek plebani koło nowego kościoła parafialnego (1896-1898, proj. T. Stryjeński) oraz Sanatorium Dłuskich (1899-1902, proj. W. Beringer). Kolejne stylowe „murowanice” to: Dworzec Tatrzański (1902-1903, proj. W. Beringer), Grand-Hotel „Stamary” (1903-1904, proj. E. Wesołowski) (il. 11) oraz gmach poczty (1904-1905, proj. E. Wesołowskiego).

Przy ul. Krupówki wzniesiony został też pierwszy budynek zwiastujący architekturę modernistyczną, ufundowany przez Władysława hr. Zamoyskiego. Był to „Bazar Polski” (1908-1910, proj. F. Mączyński; ob. Delikatesy, nr 41) (il. 12). W podobnym charakterze, ale o wyraźnych związkach ze stylem zakopiańskim był budynek Muzeum Tatrzańskiego, ostatni projekt Stanisława Witkiewicza, opracowany wspólnie z Franciszkiem Mączyńskim (1913-1922) (il. 13). 


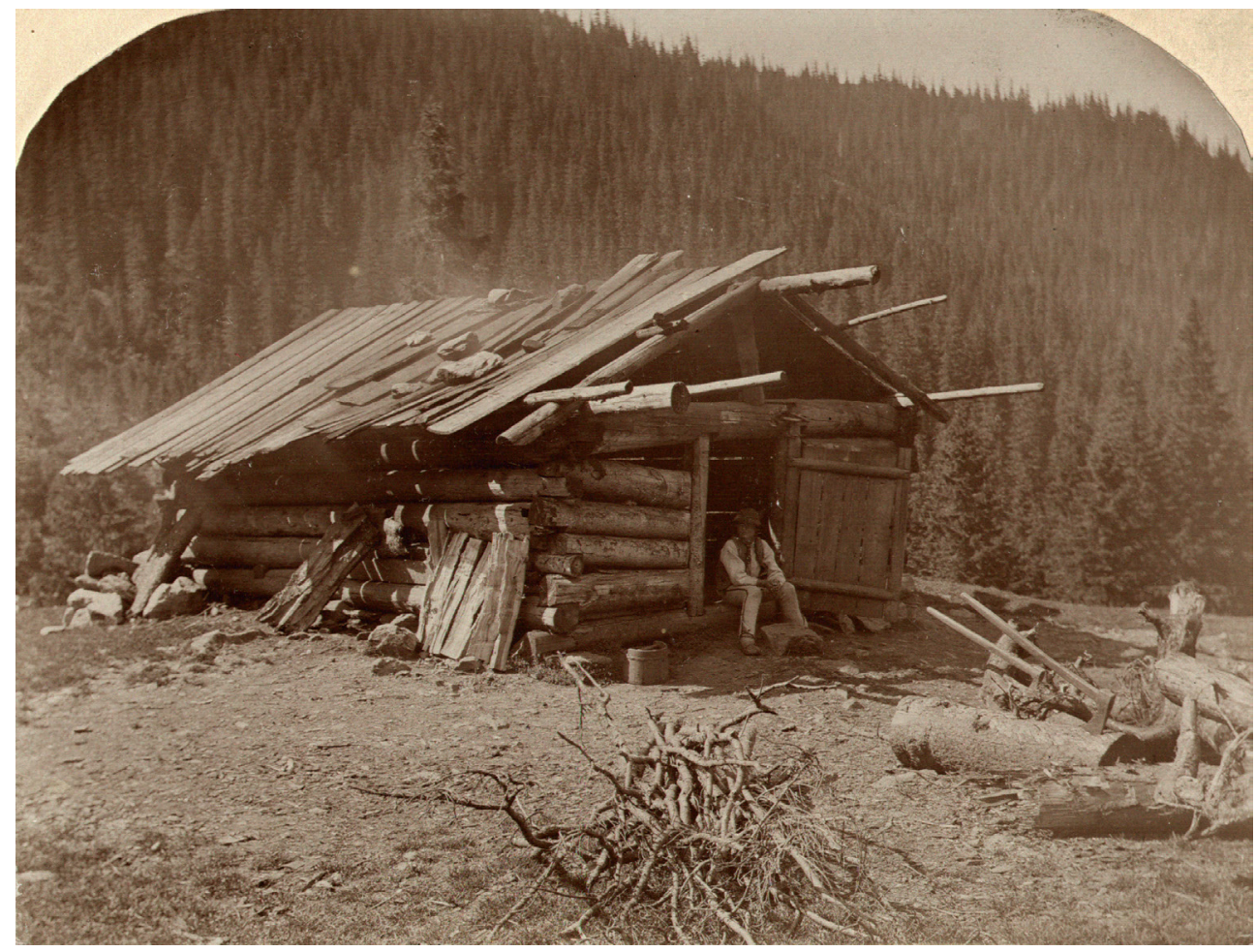

II. 1. Bacówka niskozrębowa z dachem półsochowym na Hali Pysznej.

Fot. Walery Eljasz, 1896. Tatrzański Park Narodowy, Ośrodek Dokumentacji Tatrzańskiej, Zbiory Paryskich

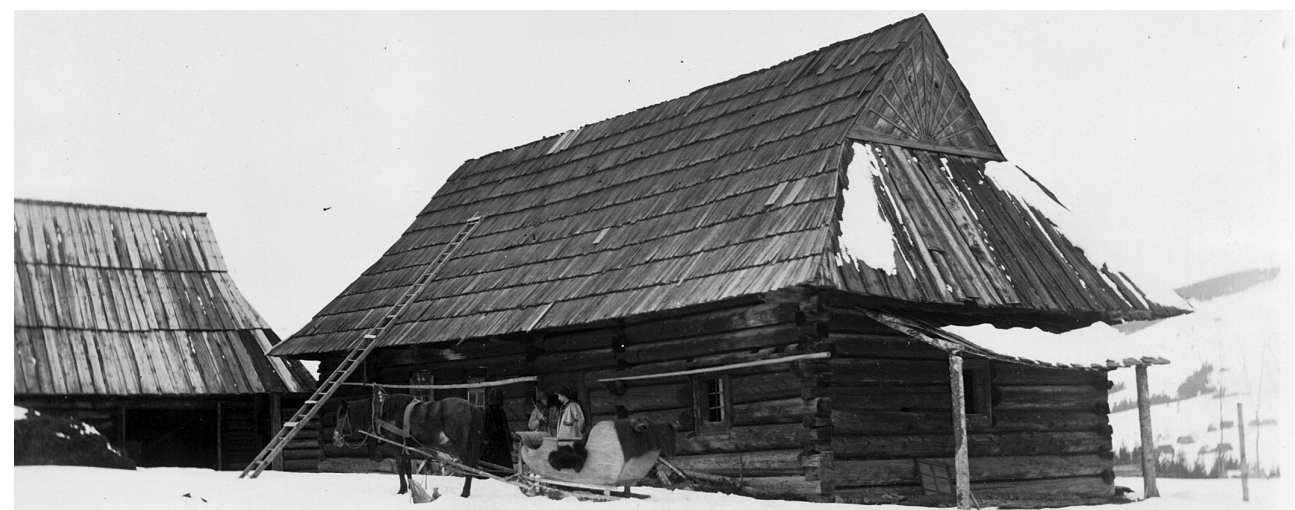

II. 2. Klasyczna chałupa podhalańska przy ul. Kościeliskiej.

Fot. Stanisław Witkiewicz, ok. 1890. Zbiory Archiwalne Muzeum Tatrzańskiego (MT-ZA), sygn. AF/2784/MT/II-20 


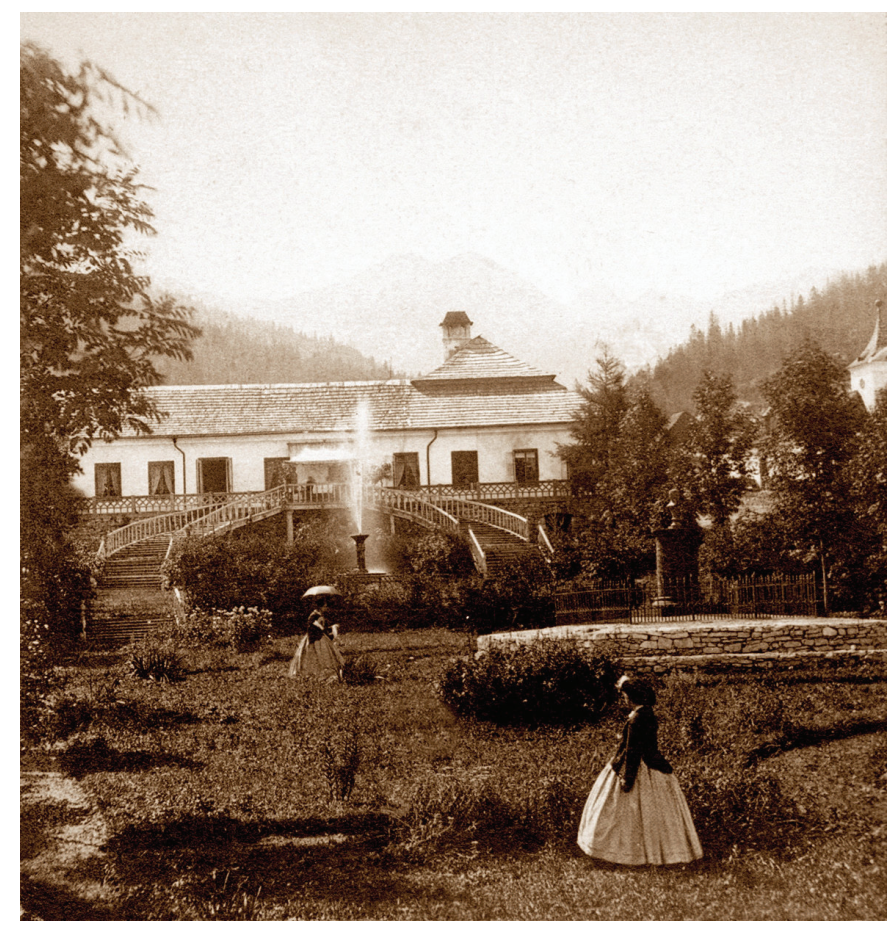

II. 3. Dwór Homolacsów w Kuźnicach. Fot. Walery Rzewuski, ok. 1860. TPN ODT, Arch. Paryskich

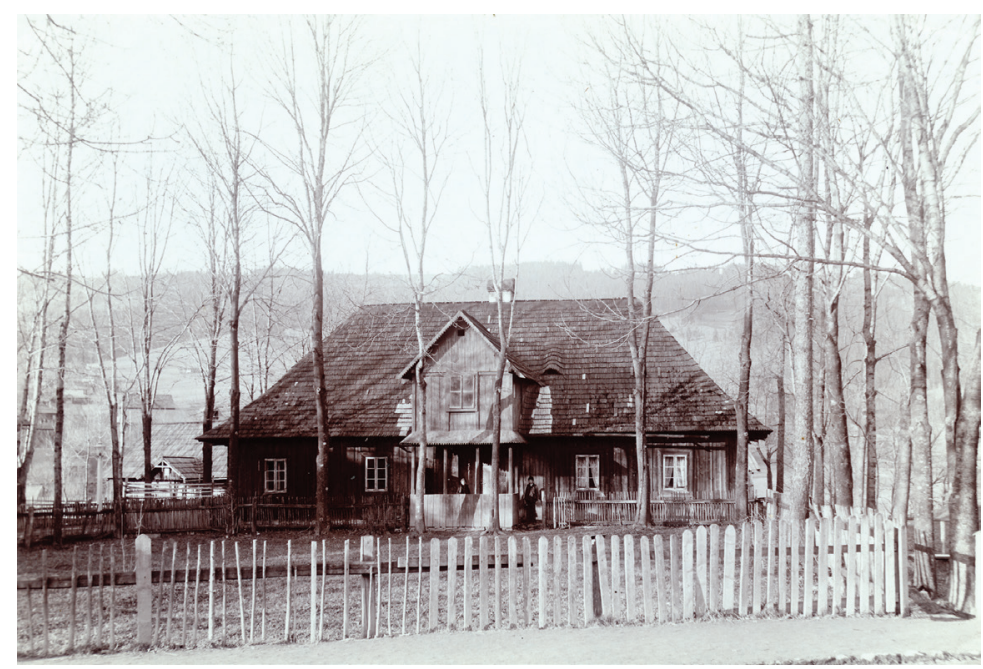

II. 4. Plebania koło kościoła pw. św. Klemensa (1851). Fot. nieznanego autora, ok. 1890. MT-ZA, sygn. AF/4789/MT/IV-012 


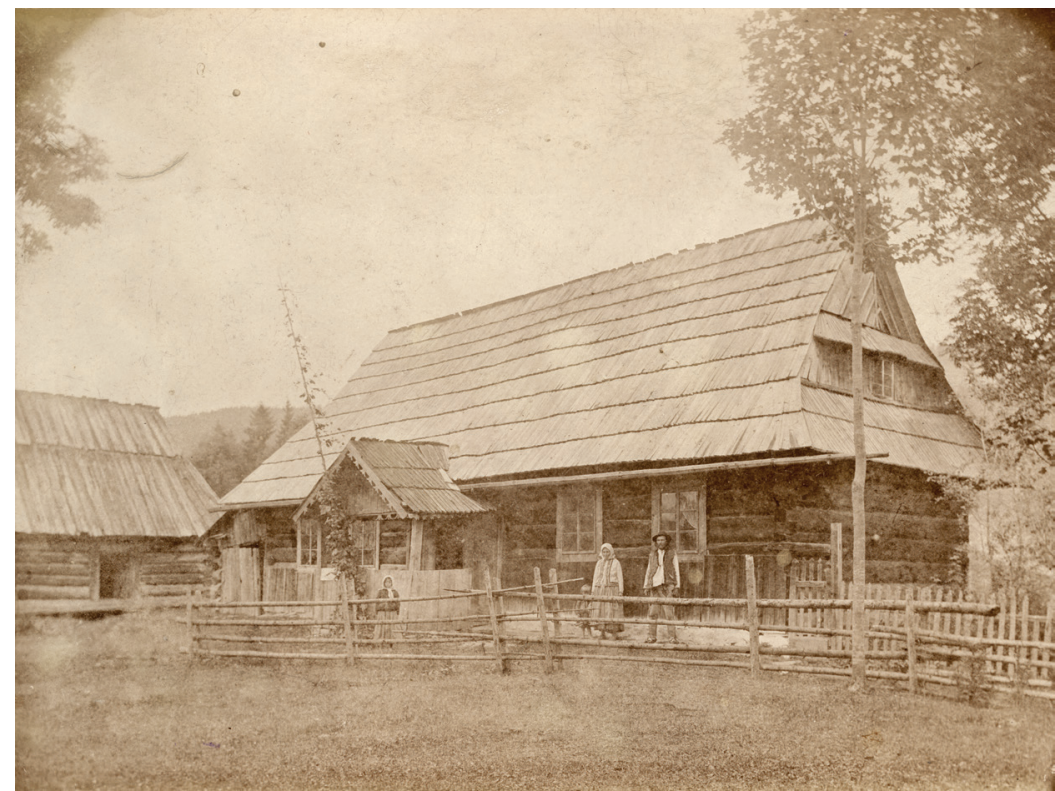

II. 5. Chałupa Macieja Sieczki, przewodnika, przy Drodze na Szymoszkową (1865). Fot. Walery Eljasz, 1894. MT-ZA, sygn. AF/13767/IV-037

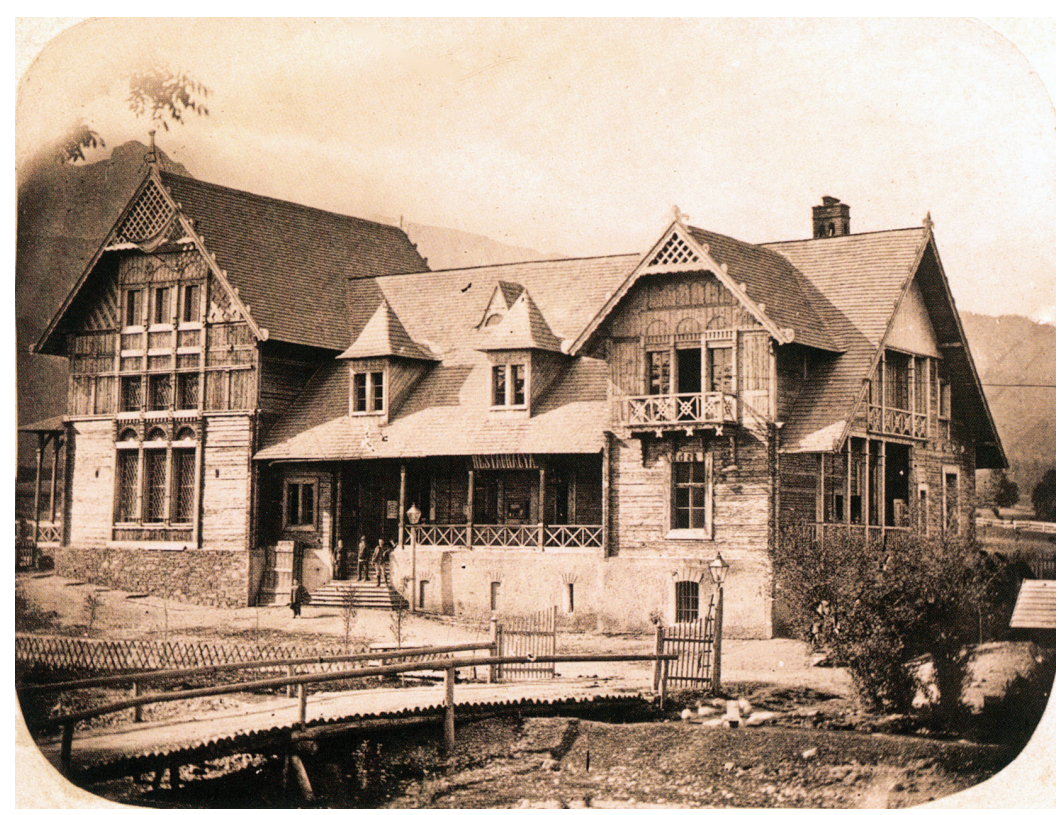

II. 6. Dwór Tatrzański przy ul. Krupówki (1881-1882, proj. K. Zaremba). Fot. nieznanego autora, ok. 1890. Tatrzański Park Narodowy, ODZ 


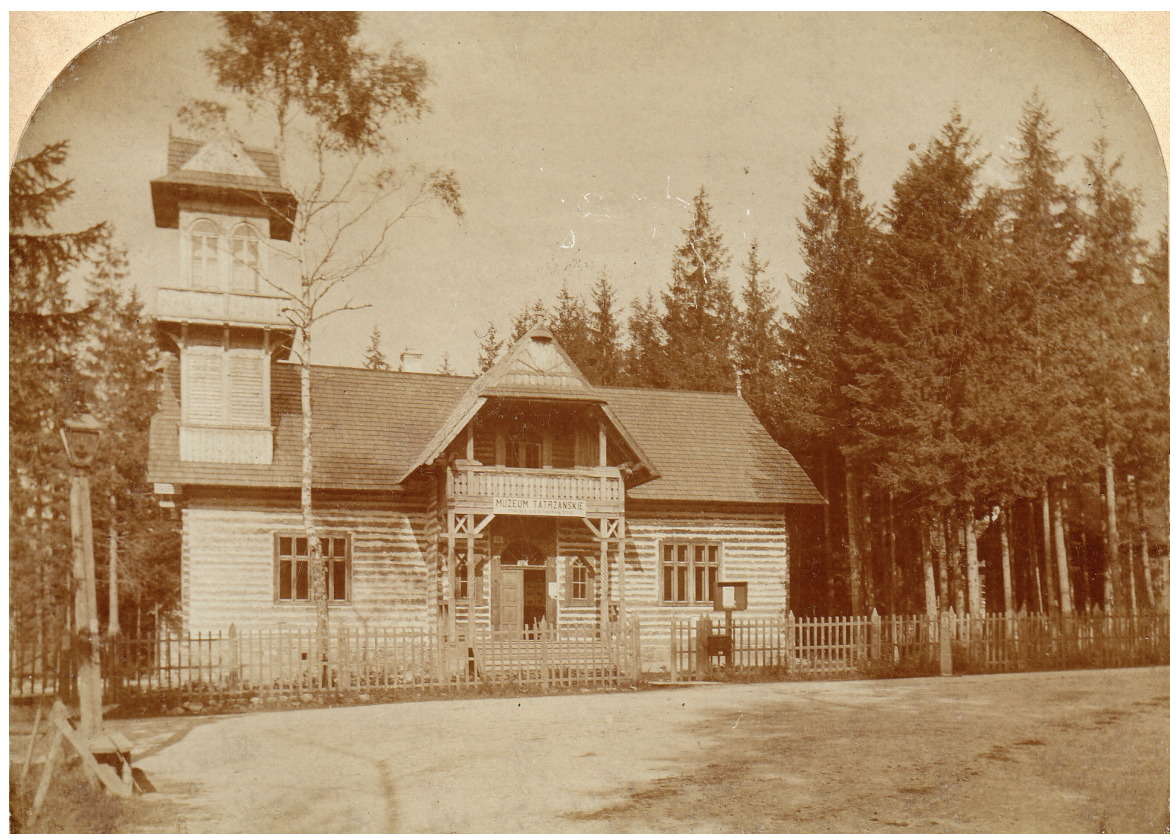

II. 7. Drewniany budynek Muzeum Tatrzańskiego przy ul. Chałubińskiego. Fot. Walery Eljasz, 1896. MT-ZA, sygn. AF/3553/MT/III-022

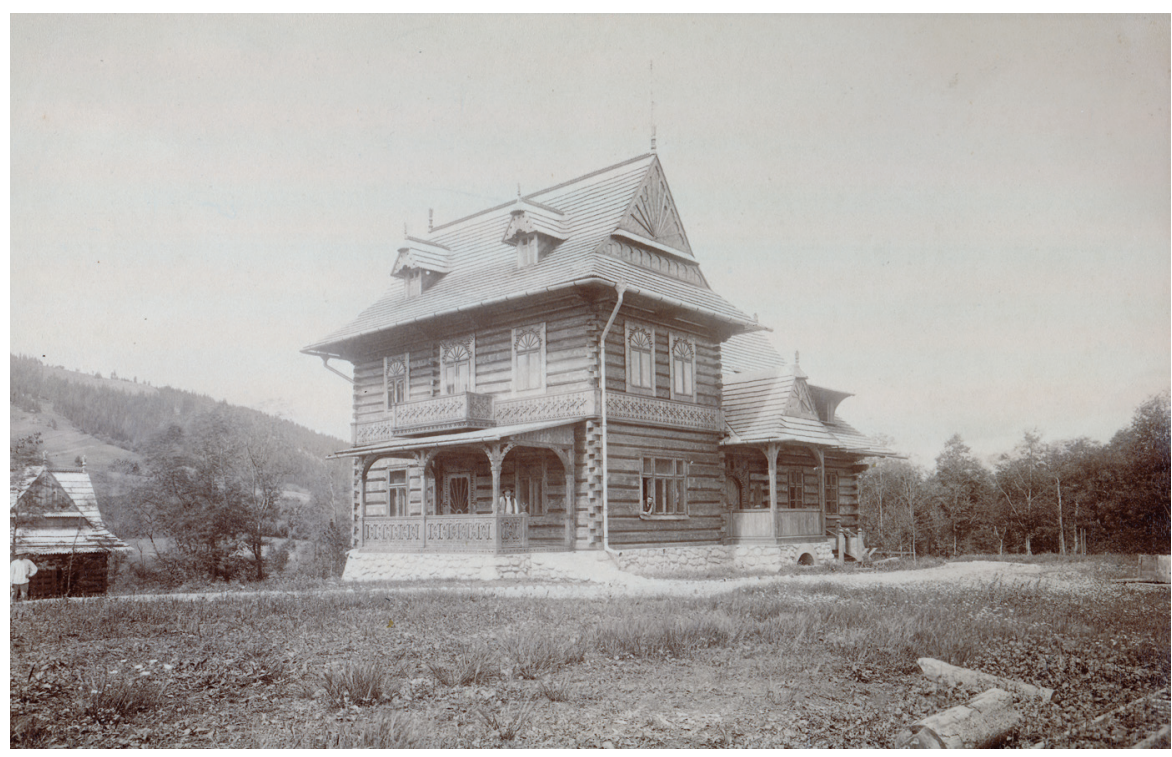

II. 8. Willa „Koliba” przy ul. Kościeliskiej (1892-1893, proj. S. Witkiewicz). Fot. Awit Szubert, 1893. MT-ZA, sygn. AF/4509/V-002 


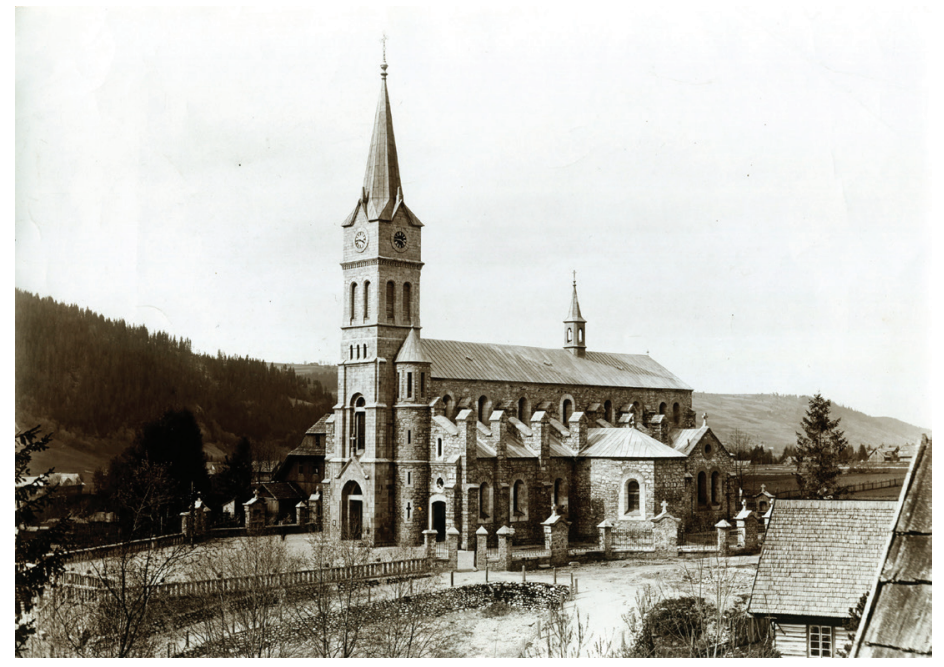

II. 9. Kościół pw. św. Rodziny (1877-1899, proj. J.P. Dziekoński).

Fot. Leonard Zwoliński, ok. 1900. MT-ZA, sygn. AF/2047/IV-004

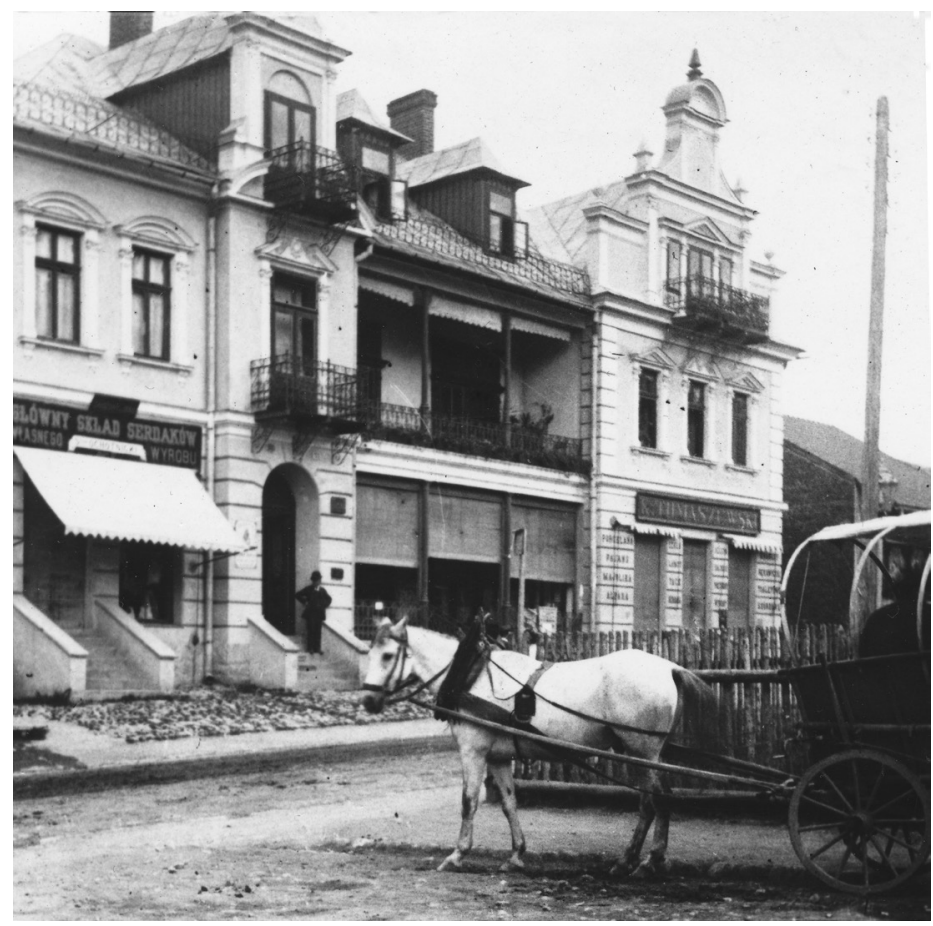

II. 10. Kamienica Zwolińskich przy ul. Krupówki (1900, proj. J. Dydek).

Fot. Leonard Zwoliński, ok. 1900. MT-ZA, sygn. AF/02537/IV-003 


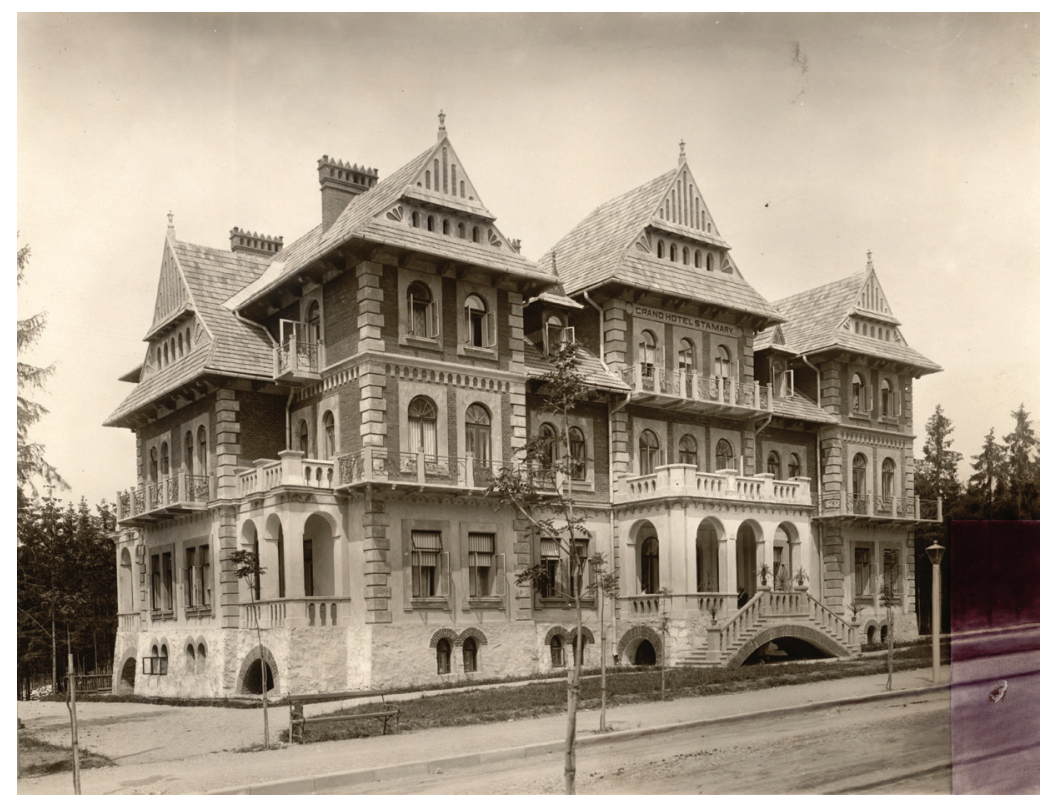

II. 11. Grand-Hotel „Stamary” przy ul. Marszałkowskiej, ob. ul. Kościuszki (1904, proj. E. Wesołowski). Fot. Eugeniusz Wesołowski, 1904. MT-ZA, sygn. AF/7710/MT

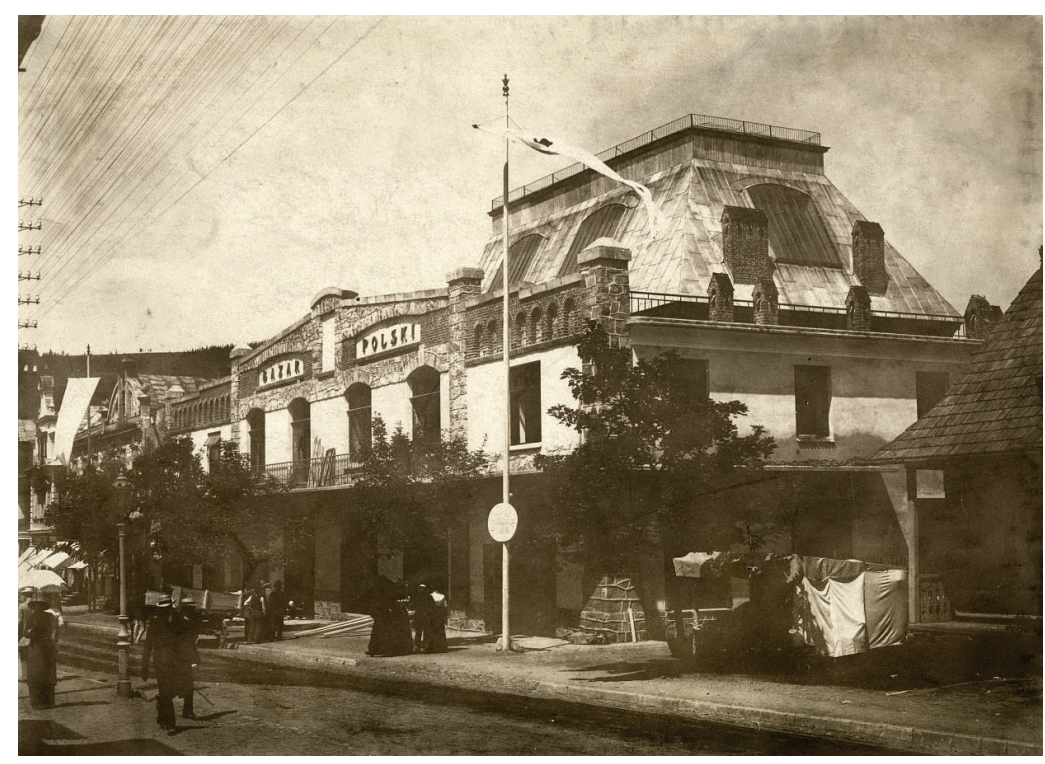

II. 12. „Bazar Polski” przy ul. Krupówki (1910-1911, proj. F. Mączyński). Fot. Henryk Schabenbeck, 1911. MT-ZA 


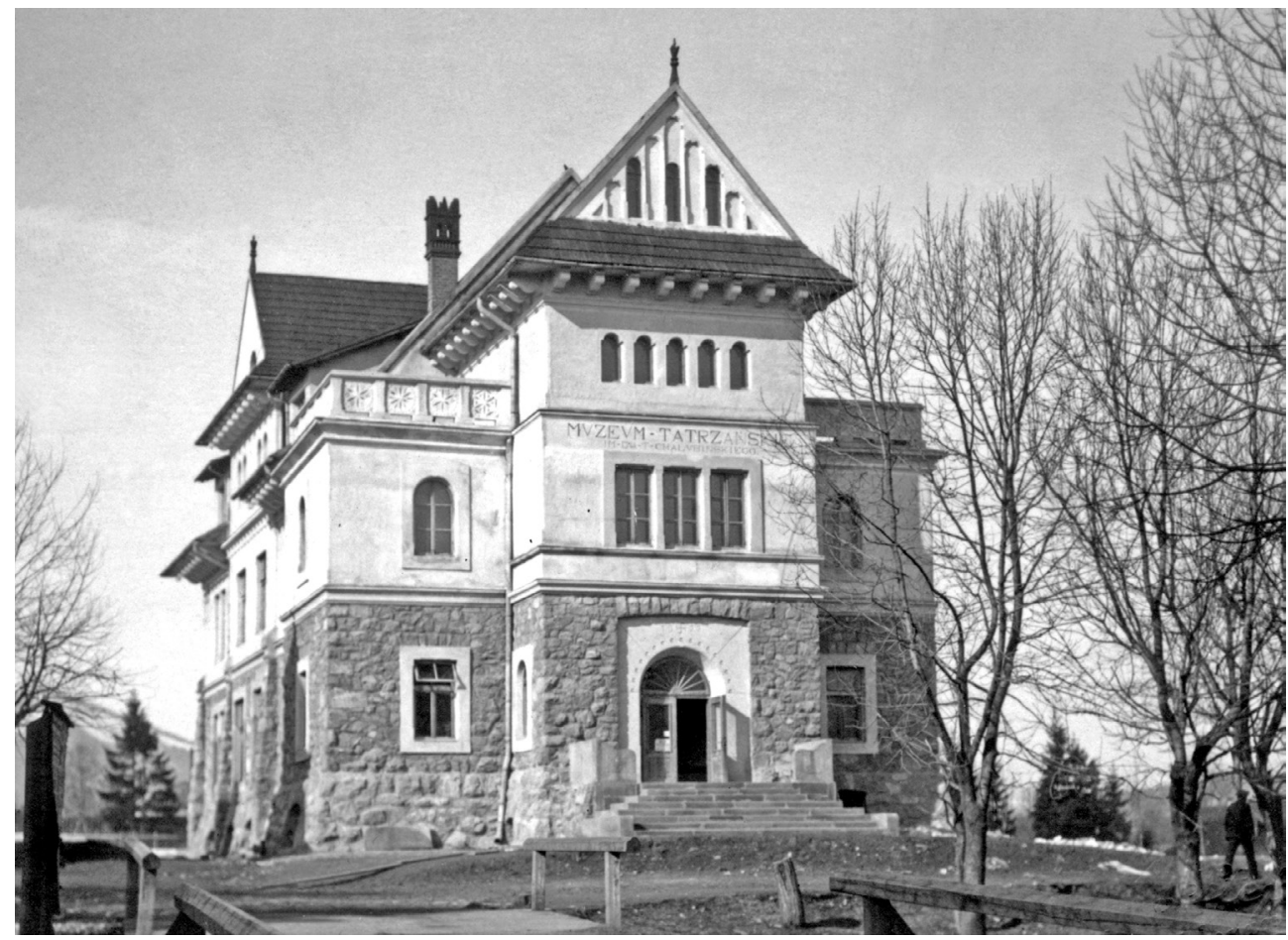

II. 13. Gmach Muzeum Tatrzańskiego w Zakopanem przy ul. Krupówki (1913-1922, proj. S. Witkiewicz, F. Mączyński).

Fot. Henryk Schabenbeck, 1923. MT-ZA, sygn. AF/3538/II-009 


\section{PRZYPISY}

1 Zob. S. Żychoń, Elementy struktury przestrzennej Polskiego i Słowackiego Podtatrza, Kraków 1970; por. tenże, Rozwój przestrzenny i budownictwo, [w:] Zakopane. Czterysta lat dziejów, t. 1, Kraków 1991, s. 419-482.

2 H. Jost, Kuźnice zakopiańskie, Warszawa 1993; tenże, Dzieje górnictwa i hutnictwa w Tatrach Polskich, Zakopane 2004.

3 J. Kracik, Mała prehistoria zakopiańskiej parafii, „Rocznik Podhalański”, 6/1992, s. 33-52.

4 W. Krygowski, Dzieje Polskiego Towarzystwa Tatrzańskiego, Warszawa-Kraków 1988.

5 Z. Moździerz, Rozwój przestrzenny i architektura Zakopanego 1600-2013, Zakopane 2013; S. Żychoń, Rozwój przestrzenny i budownictwo, [w:] Zakopane. Czterysta lat dziejów, t. 1, Kraków 1991, s. 419-482.

6 W. Białas, Budarka, [w:] Zakopane - czterysta lat dziejów, pod red. R. Dudkowej, t. 1, Kraków 1991, s. 578-599; W. Jostowa, Z zagadnień budownictwa podhalańskiego. Na marginesie organizacji skansenu, „Etnografia Polska”, 5/1962, s. 135-162; W. Matlakowski, Budownictwo ludowe na Podhalu, Lwów 1892; Z. Moździerz, Podhalańskie budownictwo ludowe, „Góry - Literatura - Kultura”, 4/2001, s. 71-98.

7 Z. Moździerz, Rozwój przestrzenny i architektura Zakopanego..., dz. cyt., s. 55-64; W. Antoniewicz, Bacówki, szałasy mieszkalne i produkcyjne oraz szopy pasterskie Tatr Polskich i Podtatrza, [w:] Pasterstwo Tatr Polskich i Podhala, t. 6: Architektura i zabudowa pasterska Tatr Polskich i Podhala oraz góralska sztuka plastyczna, Wrocław-Warszawa-Kraków 1966, s. 119-328; T.P. Szafer, Tatrzańskie bacówki pasterskie, [w:] Pasterstwo Tatr Polskich i Podhala, t. 6: Architektura i zabudowa pasterska Tatr Polskich i Podhala oraz góralska sztuka plastyczna, Wrocław-Warszawa-Kraków 1966, s. 91-117.

8 W. Matlakowski, Budownictwo ludowe..., dz. cyt.

9 H. Jost, Kuźnice zakopiańskie, dz. cyt.; tenże: Dzieje górnictwa i hutnictwa..., dz. cyt.; Z. Moździerz, Poczqtki architektury sakralnej w Zakopanem, [w:] 150 lat organizacji parafialnej w Zakopanem (1847-1997), pod red. M. Rokosza, Kraków 1998, s. 123-148; tenże, Dwór Homolacsów w Kuźnicach, „Pamiętnik Polskiego Towarzystwa Tatrzańskiego”, 18/2009 [wyd. 2010], s. 51-62.

10 Z. Moździerz: Podhalańskie budownictwo ludowe..., dz. cyt.

11 Z. Moździerz, Początki stylu zakopiańskiego, [w:] T. Jabłońska, Z. Moździerz, „Koliba”, pierwszy dom w stylu zakopiańskim, Zakopane 1994, s. 13-18 (podrozdział: Budownictwo ludowe i architektura do r. 1886); Z. Moździerz, Dwór Tatrzański. O pierwszej siedzibie Towarzystwa Tatrzańskiego pod Giewontem, „Pamiętnik Polskiego Towarzystwa Tatrzańskiego”, 18/2009 [wyd. 2010], s. 63-94.

12 Por. m.in.: T. Jabłońska, Styl zakopiański Stanisława Witkiewicza, Olszanica 2008; Z. Moździerz, Stanisława Witkiewicza klucz do stylu zakopiańskiego, „Góry-Literatura - Kultura”, 2/1996, s. 107-114; tenże, Geneza i rozwój stylu zakopiańskiego, [w:] Dom „Pod Jedlami 
Pawlikowskich, Wydawnictwa MT, Zakopane 2003, s. 11-100; tenże, Styl zakopiański w architekturze i sztuce sakralnej, [w:] Kaplica Najświętszego Serca Pana Jezusa w Jaszczurówce (1907-2007), pod red. tegoż, Zakopane 2007, s. 7-48; Z. Pytel, Witkiewiczowska architektura sakralna w Zakopanem, uzup. i red. Z. Moździerz, Zakopane 1999.; B. Tondos, Styl zakopiański i zakopiańszczyzna, Wrocław 2004.

13 Z. Moździerz „Murowanice” w stylu zakopiańskim, [w:] Gmach Muzeum Tatrzańskiego, Wydawnictwa MT, Zakopane 2005, s. 13-104; tenże, Kościół Najświętszej Rodziny w Zakopanem, Zakopane 2006; tenże, O powstaniu „Bazaru Polskiego” w Zakopanem, [w:] W stulecie Bazaru Polskiego. Henryk Grohman i grafika Młodej Polski, Zakopane 2011, s. 4-11.

14 Por. Z. Moździerz, Historia zakopiańskich wodociqgów i kanalizacji (1895-1992), [w:] Zakopiańskie wodociqgi i kanalizacja 1905-2005, pod red. J.M. Roszkowskiego, Zakopane 2006, s. 13-178.

\section{BIBLIOGRAFIA}

Antoniewicz W., Bacówki, szałasy mieszkalne i produkcyjne oraz szopy pasterskie Tatr Polskich i Podtatrza, [w:] Pasterstwo Tatr Polskich i Podhala, t. 6: Architektura i zabudowa pasterska Tatr Polskich i Podhala oraz góralska sztuka plastyczna, Wrocław-Warszawa-Kraków 1966, s. 119-328.

Białas W., Budarka, [w:] Zakopane - czterysta lat dziejów, pod red. R. Dudkowej, t. 1, Kraków 1991, s. 578-599.

Białkiewicz Z.J., Feliks Księżarski (1820-1884). Krakowski architekt epoki historyzmu, Księgarnia Akademicka, Kraków 2008.

Chrzanowski T., Kornecki M., Sztuka ziemi krakowskiej, Kraków 1982.

Jabłońska T., Styl zakopiański Stanisława Witkiewicza, Olszanica 2009.

Jost H., Dzieje górnictwa i hutnictwa w Tatrach Polskich, Zakopane 2004.

Jost H., Kuźnice zakopiańskie, Warszawa 1993.

Jostowa W., Z zagadnień budownictwa podhalańskiego. Na marginesie organizacji skansenu, „Etnografia Polska”, 5/1962, s. 135-162.

Kracik J., Mała prehistoria zakopiańskiej parafii, „Rocznik Podhalański”, 6/1992, s. 33-52.

Krygowski W., Dzieje Polskiego Towarzystwa Tatrzańskiego, Warszawa-Kraków 1988.

Matlakowski W., Budownictwo ludowe na Podhalu, Lwów 1892.

Moździerz Z., Architektura i rozwój przestrzenny Zakopanego 1600-2013, Wydawnictwa TMT, Zakopane 2013.

Moździerz Z., Dwór Homolacsów w Kuźnicach, „Pamiętnik Polskiego Towarzystwa Tatrzańskiego", 18/2009 [wyd. 2010], s. 51-62. 
Moździerz Z., Dwór Tatrzański. O pierwszej siedzibie Towarzystwa Tatrzańskiego pod Giewontem, „Pamiętnik Polskiego Towarzystwa Tatrzańskiego”, 18/2009 [wyd. 2010], s. 63-94. Moździerz Z., Geneza i rozwój stylu zakopiańskiego, [w:] Dom „Pod Jedlami” Pawlikowskich, Wydawnictwa MT, Zakopane 2003, s. 13-100.

Moździerz Z., Historia zakopiańskich wodociagów i kanalizacji (1895-1992), [w:] Zakopiańskie wodociagi i kanalizacja 1905-2005, pod red. J.M. Roszkowskiego, Zakopane 2006, s. 13-178.

Moździerz Z., Kościół Najświętszej Rodziny w Zakopanem, Zakopane 2006.

Moździerz Z., „Murowanice” w stylu zakopiańskim, [w:] Gmach Muzeum Tatrzańskiego, Wydawnictwa MT, Zakopane 2005, s. 13-104.

Moździerz Z., O powstaniu „Bazaru Polskiego” w Zakopanem, [w:] W stulecie Bazaru Polskiego. Henryk Grohman i grafika Młodej Polski, Zakopane 2011, s. 4-11.

Moździerz Z., Od szałasu do apartamentowca, „Góry - Literatura - Kultura”, 9/2015, s. 93-117.

Moździerz Z., Poczq̨tki architektury sakralnej w Zakopanem, [w:] 150 lat organizacji parafialnej w Zakopanem (1847-1997), pod red. M. Rokosza, Kraków 1998, s. 123-148.

Moździerz Z., Poczq̨tki stylu zakopiańskiego, [w:] T. Jabłońska, Z. Moździerz, „Koliba”, pierwszy dom w stylu zakopiańskim, Zakopane 1994, s. 13-18.

Moździerz Z., Podhalańskie budownictwo ludowe, „Góry - Literatura - Kultura”, 4/2001, s. 71-98.

Moździerz Z., Stanisława Witkiewicza klucz do stylu zakopiańskiego, „Góry - Literatura - Kultura", 2/1996, s. 107-114.

Moździerz Z., Styl zakopiański w architekturze i sztuce sakralnej, [w:] Kaplica Najświętszego Serca Pana Jezusa w Jaszczurówce (1907-2007), pod red. Z. Moździerza, Zakopane 2007, s. 7-48.

Olszewski A.K., Nowa forma w architekturze polskiej 1900-1925. Teoria i praktyka, Wrocław-Warszawa-Kraków 1967.

Olszewski A.K., Poszukiwanie stylu narodowego w architekturze polskiej ostatniego stulecia, „Architektura”, 3-4/1977, s. 55-66.

Pinkwart M., Długołęcka-Pinkwart L., Zakopane. Przewodnik historyczny, Bielsko-Biała 2003.

Pytel Z., Witkiewiczowska architektura sakralna w Zakopanem, uzup. i red. Z. Moździerz, Zakopane 1999.

Ross J., Architektura drewniana w polskich uzdrowiskach karpackich (1835-1914), [w:] Sztuka 2. połowy XIX wieku. Materiały sesji SHS, Łódź, listopad 1971, Warszawa 1973, s. 151-172.

Szafer T.P., Tatrzańskie bacówki pasterskie, [w:] Pasterstwo Tatr Polskich i Podhala, t. 6: Architektura i zabudowa pasterska Tatr Polskich i Podhala oraz góralska sztuka plastyczna, Wrocław-Warszawa-Kraków 1966, s. 91-117 [reprint pod zm. tyt.: Z genezy tatrzańskiego dachu, „Architektura Współczesna Ziem Górskich”, 1/1993, s. 19-80].

Śmiałowski R., Architektura i budownictwo w Tatrach Polskich, Warszawa 1959. 
Tołłoczko Z., Jeszcze o „stylu zakopiańskim” i jego wpływie na architekturę modernistycznq. Przyczynek do kwestii zaniku ludowej inspiracji w architekturze końca XX wieku, „Czasopismo Techniczne", 1-A /2000, s. 16-25.

Tondos B., Styl zakopiański i zakopiańszczyzna, Wrocław 2004.

Witkiewicz S., Styl zakopiański, z. 2: Ciesielstwo, Lwów 1911.

Zieliński J., Wpływ stylu zakopiańskiego na rozwój regionalizmu w architekturze polskiej próba retrospekcji, [w:] Aktualne problemy planistyczne i architektoniczne w zespołach architektury regionalnej i ich squsiedztwie. Materiały z III Ogólnopolskiego Sympozjum Architektury Regionalnej, pod red. Z. Radziewanowskiego, J. Zielińskiego, KrakówZakopane 1982, s. 183-213.

Żychoń S., Elementy struktury przestrzennej Polskiego i Słowackiego Podtatrza, Kraków 1970. Żychoń S., Rozwój przestrzenny i budownictwo, [w:] Zakopane. Czterysta lat dziejów, t. 1, Kraków 1991, s. 419-482. 